IRSTI 34.27 .23

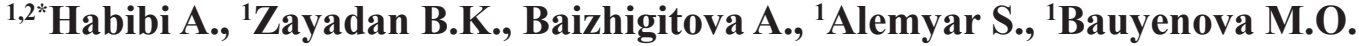 \\ ${ }^{1}$ Department of Biology and Biotecnology al-Farabi Kazakh National University, Kazakhstan, Almaty \\ ${ }^{2}$ Department of Agronomy, Faculty of Agriculture, Baghlan University, Afghanistan, Baghlan, \\ e-mail: ainullah.habibi1@yahoo.com
}

\title{
THE EFFECT OF ISOLATED CYANOBACTERIA ON RICE SEED GERMINATION AND GROWTH
}

Cyanobacteria make a major contribution to the fertility of soil. It has been suggested that cyanobacteria assist higher plant growth by supplying growth substances. There are numerous works about effect of cyanobacteria in paddy soils and rice growth in the world but very little research has been carried out in Afghanistan. In this research, cyanobacteria Anabaena sp were isolated from paddy soils of Baghlan Province of Afghanistan. The isolated cyanobacteria Anabaena sp was used as inoculums on three common varieties of Afghanistan's rice separately for two hours. After 10 days the result revealed that inoculation of rice seeds by cyanobacteria extracts can enhance seed germination, plant height and length of root in all treated seeds in comparing seeds control by water. In the next stage, seeds under experiment separately inoculated by cyanobacteria extracts and cultivated in nonorganic silt soil as well as treated by cyanobacteria extracts. After 12 days the morphological view showed differences in shoot height of treated plants in comparing to plant controlled by water. Therefore cyanbacteria Anabaena sp. recommended as an effective biofertilizer in paddy fields of Afghanistan.

Key words: Cyanobacteria, inoculation, biofertilizer, Baghlan, Shamarq, Chashmaishir.

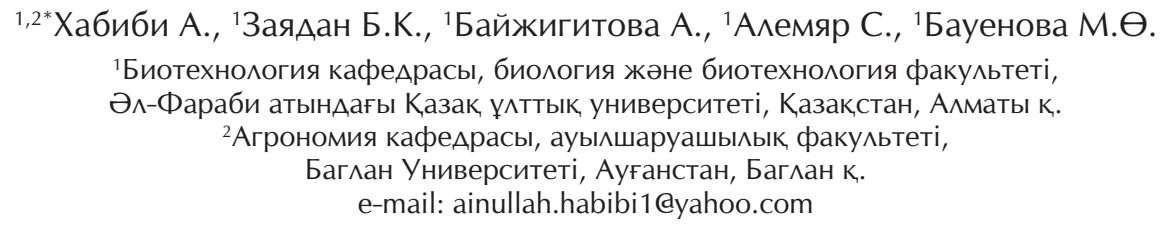

\section{Күріштің өсуі мен тұқымның өнуіне бөлініп алынған} цианобактериялардың әсері

Цианобактериялар топпырақтың құнарлылығына үлкен үлесін қосады. Цианобактериялар өсімдіктердің жоғары деңгейле өсіп дамуына әсер ететіндігі жайлы мәліметтер бар. Әлем бойынша цианобактериялардың күріштің өсуіне және топыраққа әсері жайлы жұмыстар өте көп кездеседі, дегенмен Ауғанстанда бұл зерттеулер өте аз жүргізілген. Бұл зерттеуде Аnabaena sp. цианобактериясы Ауғанстанның Бағлан қаласы провинциясының топырағынан бөлініп алынды. Бөлініп алынған Anabaena sp.цианобактериясы құйылған ыдыста, Ауғанстанның үш түрлі күріштері екі сағат бойы ұсталынды. 10 тәуліктен соң, цианобактерия экстрактісінде ұсталынған күріш дәндерінің, өсімдіктің ұзындығы және тамыр ұзындығы, суда ұсталынған Аәндермен салыстырғанда, артқаны байқалады. Тәжірибенің келесі кезеңінде күріш дәндері цианобактериямен байытылған топырақта және сумен байытылған топырақтарда өсірілді. 12 тәулік өткен соң цианобактериямен байытылған топырақта өскен өсімдіктің, сумен байытылған топырақта өскен өсімдіктен ұзындығымен, морфологиясы бойынша әртүрлілігін көрсетеАі. Сондықтан, Anabaena sp цианобактериясы Ауғанстанның күріш алқаптарына тиімді биотыңайтқыш ретінде ұсыныла алады.

Түйін сөздер: цианобактерия, инокуляция, биотыңайтқыш, Баглан, Шамарқ, Чашмайшир. 


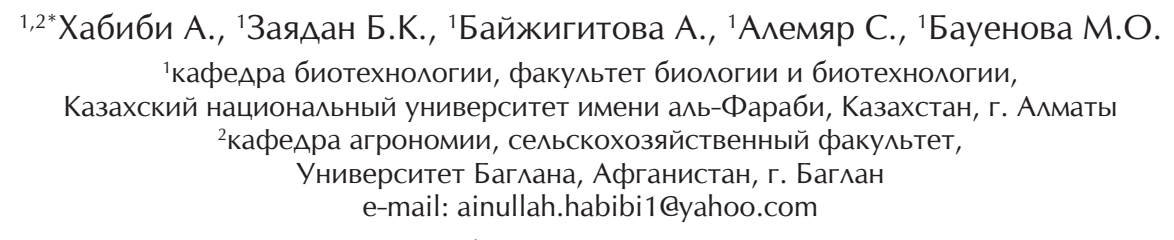

\title{
ВАияние выделенных цианобактерий на прорастание семян и рост риса
}

\begin{abstract}
Цианобактерии вносят большой вклад в плодородие почвы. Показано, что цианобактерии синтезируют вещества, стимулирующие более высокий рост растений. Существует множество работ о влиянии цианобактерий на урожайность рисовых полей, но очень мало исслеАований проведено в Афганистане. В этом исследовании цианобактерия Anabaena sp. была вылелена из рисовых полей провинции Баглан, Афганистан. Вылеленную цианобактерию Anabaena sp. использовали в качестве инокулята на трех разновидностях риса Афганистана в течение двух часов. По истечению 10 суток было показано, что инокуляция семян риса цианобактерией улучшила всхожесть семян, рост растений и Алину корня во всех обработанных семенах по сравнению с контролем. На следующем этапе эксперимента семена подвергали раздельной инокуляции экстрактами цианобактерии и культивировали в неорганической иловой почве. Через 12 Аней результаты опыта показали различия в высоте побегов обработанных растений по сравнению с контролем. В связи с этим цианбактерия Anabaena sp. рекомендуется в качестве эффективного биоудобрения Аля рисовых полей Афганистана.
\end{abstract}

Кмючевые слова: цианобактерия, инокуляция, биоудобрения, Баглан, Шамарк, Чашмайшир.

\section{Introduction}

Cyanobacteria are photosynthetic prokaryotes and colonizing microorganisms that are found throughout the world and they are exceptionally well adapted to a wide array of environmental conditions (Paerl et al., 2000:11-26, Karthikeyan et al., 2008:87-91 and Kirlwood et al., 2008:453-465). These organisms are one of the major components of the nitrogen fixing biomass in paddy fields. The agricultural importance of cyanobacteria in rice cultivation is directly related with their ability to fix nitrogen and other positive effects for plants and soil. After water, nitrogen is the second limiting factor for plant growth in many fields and deficiency of this element is met by fertilizers (Malik et al. 2001:12171220). The excessive use of chemical fertilizers has generated several environmental problems including the greenhouse effect, ozone layer depletion and acidification of water. These problems can be tackled by use of biofertilizers (Choudhury and Kennedy 2005:1625-1639, Rai 2006:1-28). Biofertilizers, more commonly known as microbial inoculants, include bacteria (Azotobacter), cyanobacteria and mycorrhizal fungi; they are natural, beneficial and ecological friendly, they also provide nutrients for the plants and maintain soil structure (Board 2004:949). Over the past six decades, reports have been published on the use of cyanobacterial inoculants (algalization) to enhance biological N2 fixation in wetland rice fields. Cyanobacteria play an important role in maintenance and build-up of soil fertility, consequently increasing rice growth and yield as a natural biofertilizer (Song et al. 2005:131-140). The acts of these algae include: (a) Increase in soil pores with having filamentous structure and production of adhesive substances. (b) Excretion of growthpromoting substances such as hormones (auxin, gibberellin), vitamins, amino acids (Roger and Reynaud 1982:147-168, Rodriguez et al. 2006:14). (c) Increase in water- holding capacity through their jelly structure (Roger and Reynaud 1982:147168). (d) Increase in soil biomass after their death and decomposition. (e) Decrease in soil salinity. (f) Preventing weeds growth. (g) Increase in soil phosphate by excretion of organic acids (Wilson 2006:9-10). The indirect promotion of plant growth occurs when cyanobacteria prevent or counter deleterious effects of one or more phytopathogenic microorganisms (Moussa and Shanab, 2001:267281, Rizk, 2006:212-215, Kim, 2006:138-142, Abo-Shady et al., 2007:3029-3038, Tassara et al., 2008:487-492, Kim and Kim, 2008:242-248). Several studies have reported that cyanobacteria can improve the plant growth by improving the soil structure as they have potential to secrete extracellular polysaccharides that help in soil aggregation and water retention (Hill et al., 1994:126-148, Mazor et al., 1996:121-130, Maqubela et al., 2009:79-92). In addition, the use of cyanobacteria can increase the carbon and nitrogen status of soil (De Caire et al., 2000:1985-1987, De Cano et al., 2002:2421-2431, Azia and Hashem, 2004:309-3011, Pandey et al., 2005:451-457, Malam Issa et al., 2007:209-219, 
Obana et al., 2007:641-646, Nisha et al., 2007:4956, Swarnalakshmi et al., 2007:307-313, Maqubela et al., 2009:79-92, Saadatnia and Riahi, 2009:207212, Maqubela et al., 2009:79-92). Most paddy soils have a natural population of cyanobacteria which provides a potential source of nitrogen fixation at no cost (Mishra and Pabbi 2004:6-10). The paddy field ecosystem provides a favorable environment for the growth of cyanobacteria with respect to their requirements for light, water, high temperature and nutrient availability. This could be the reason for more abundant cyanobacteria growth in paddy soils than in upland soils (Roger and Reynaud 1982:147-168, Kondo and Yasuda 2003:105-111). In this research we studded the effect of isolated cyanobacteria on seed germination and plant growth on three common varieties of Afghanistan's rice (IR rice, Long red rice and Medium red rice)

\section{Materials and methods}

The aim of this research was effect of isolated cyanobacteria as a biofertilizer on three common varieties of rice plants in Afghanistan.

Soil samples were collected from the depth of $0-5 \mathrm{~cm}$ of soil surface in paddy fields of Shamarq and Chashmaishir villages of Baghlan province in the north east of Afghanistan in August, 2016. Soil sample transferred to the laboratory of photobiotechnology, Faculty of Biology and Biotechnology, al-Farabi KazNU. Standard microbiological and algological research methods carried out for isolation and purification of nitrogen fixing cyanobacteria used the bellow nutrient mediums.

Gromov's No6 nutrient medium consisted of (per liter of distilled water) $\mathrm{NaNO}_{3}(1 \mathrm{~g})$, $\mathrm{K}_{2} \mathrm{HPO}_{4}(0.2 \mathrm{~g}), \mathrm{MgSO} 4 \times 7 \mathrm{H}_{2} \mathrm{O}(0.2 \mathrm{~g}), \mathrm{CaCl}_{2}$ $(0.15 \mathrm{~g}), \mathrm{NaHCO} 3(0.2 \mathrm{~g})$, EDTA $(1 \mathrm{ml})$, solution of microelement ${ }^{1}(1 \mathrm{ml})$ and solution of micoelement ${ }^{2}$ $(1 \mathrm{ml})$.

BG11nitrogen free medium consisted (per liter of distilled water) $\mathrm{K}_{2} \mathrm{HPo}(40 \mathrm{mg}), \mathrm{MgSO}_{4} \times$ $7 \mathrm{H} 2 \mathrm{O}(75 \mathrm{mg}), \mathrm{CaCl}_{2} \times 2 \mathrm{H}_{2} \mathrm{O}(36 \mathrm{mg}), \mathrm{Na}_{2} \mathrm{CO} 3(20 \mathrm{mg})$, Citrate $\mathrm{Na}(6 \mathrm{mg})$, FeNH4 Citrate $(6 \mathrm{mg})$, Solution of microelements ${ }^{1}, 1 \mathrm{ml}$ ) and solution of microelement ${ }^{2}$, (1ml). The collected soil was cultured in Petri dishes with a sterile Gromov's No6 liquid nutrient medium. After 14 days of cultivation, green algae grown on the surface of cultured medium in Petri dishes.

Green specimen of microalgae from the surface of cultured medium took by loop and transferred to the sterile liquid nutrient medium in the sterile flasks under the condition of lab box. The cultured flasks were placed under the light (2000 lux) for 10 days. After 10 days the cultured growth and made the color of liquid nutrient green. For dilution and repeating the culture, $1 \mathrm{ml}$ of specimen from the liquid culture was took by pipette and transferred to sterile liquid nutrient medium in conical flasks, while the liquid was poured into the flasks in such a way that the volume occupied was not more than 1 / $3-1 / 4$ of the volume of the flask. The culture was placed under the same intensity of light for 12 days. The specimen from the growth culture took by loop and transferred to the new sterile BG11nitrogen free medium in the sterile flasks and placed under the same light condition 2000 lux. Algological pure culture was isolated by proper microscoping control (Gollerbah et al., 1951,644). The cultures in the liquid medium were hand shaken daily to prevent sticking of the cyanobacteria to the wall of the container.

To evaluate the activity of cyanobacteria, a suspension of cyanobacteria . A volume of $1 \mathrm{ml}$ or more, depending on the purity of the storage culture, was transferred immediately to Petri dishes on frozen nutrient agar mixed with Gromov's medium and distributed on the surface of the agar with a sterile spatula.

For purification of cyanobacteria 0.1 gr antibiotic (ampicillin) added to $1 \mathrm{ml}$ of water. 30 micro liters from the suspension antibiotic were distributed on the surface of each Petri dish with a sterile spatula.

The Petri dishes were placed in the light until the colonies formed. From the grown colony, specimen was transferred again to a liquid medium by loop. Pure culture of cyanbacteria Anabaena sp. was grown in conical flasks $250-1000 \mathrm{ml}$ under the light (2000 lux) and temperature of $27-28 c^{0}$ . Microscopy of isolated cultures of cyanobacteria is carried out with the help of MX 300T ( Austria) and Axio Imager A1(«Carl Zeiss», Germany) microscopes (Gollerbah et al., 1951,644).

- Germination of seeds: Three variety of common rice (IR rice, medium red rice and long length red rice) collected from Baghlan province of Afghanistan and transferred to the laboratory of photobiotechnology, Faculty of Biology and Biotechnology, al-Farabi KazNU.

Petri dishes were prepared in the following way: sterile filter paper corresponding to the size of the cups bottom was placed at the bottom of sterile cups. Petri dishes were put in autoclave for one hour. Seeds of rice were soaked for two hours in suspensions of cyanobacteria extracts and in sterile water (control), and then seeds were placed in Petri dishes in the amount of 8 pieces in each 
cup. Cultured seeds were placed under the light for 10 days and every 24 hours the seeds under experiment were treated with $1 \mathrm{ml}$ of sterile water. After 7 days germination of seeds, total length of shoots and roots measured by ruler in each Petri dish and counted the number of not germinated seeds for each cup.

- Seed cultivation on soil: Nonorganic silt soil were incubated and put in plastic cups not occupied more than 3/4 parts of the cups. As previous new seeds of the test plants were soaked for one hour in suspensions of cyanobacteria and in sterile water to control. Then the amount of 10 seeds cultivated in soil of each cups. Cups were placed under the light for 12 days and every 24 hours the cultivated seeds in experiment were treated with $10 \mathrm{ml}$ cyanobacteria extracts and sterile water to control for 12 days (Saadatnia and Riahi., 2009:207-212).

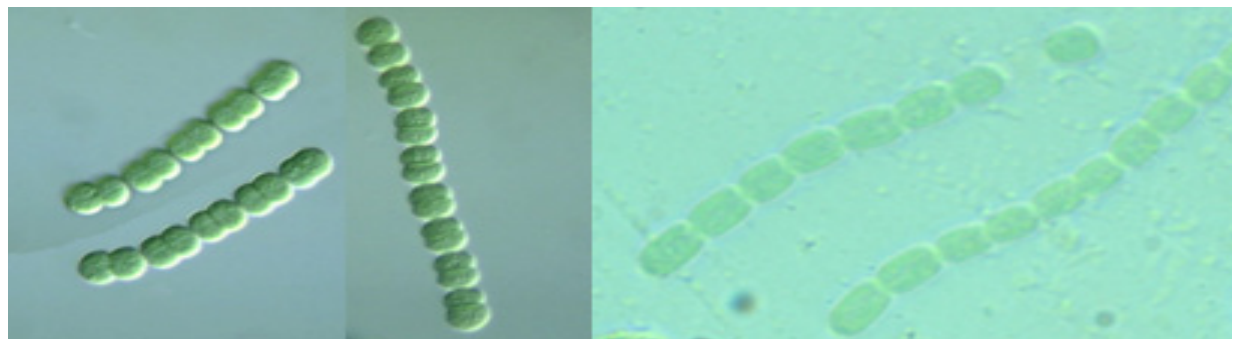

Culture of Cyanobacteria anabaena sp (Zoom. 1x 100)

Figure 1 - The morphology of isolated cyanobacteria, Anabaena sp.
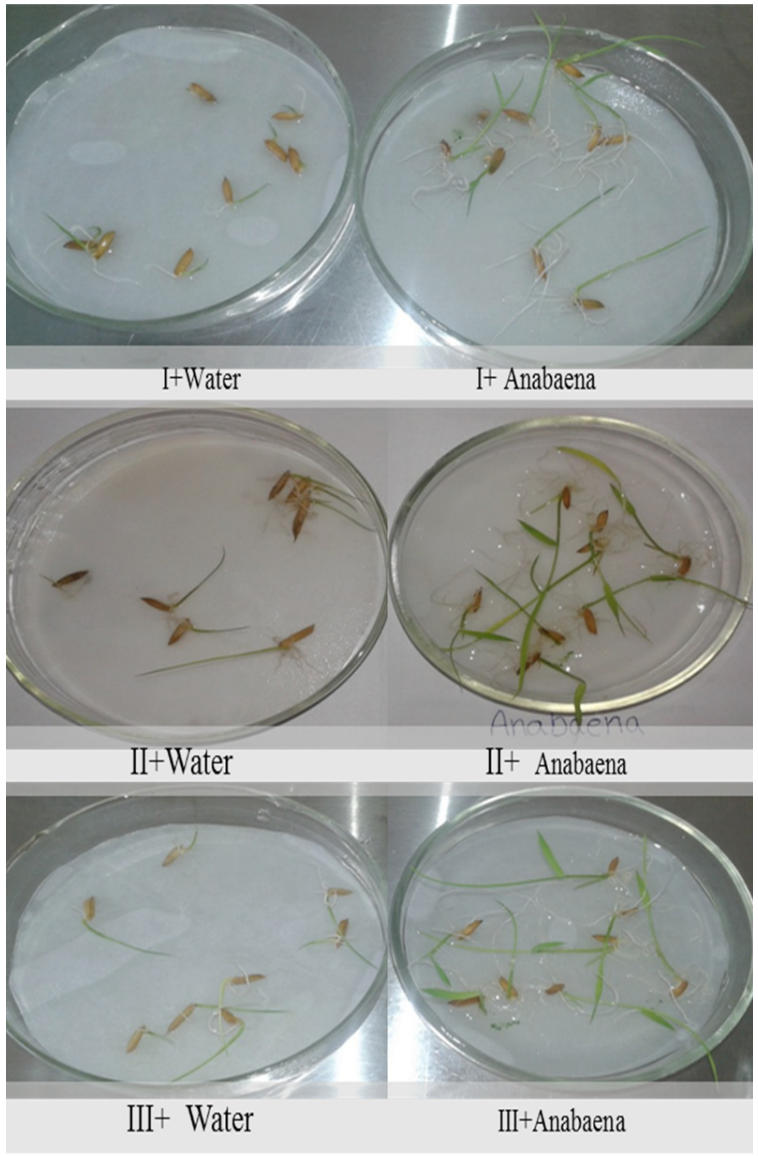

Figure 2 - Three varieties of rice (I-IR rice, II-Long red rice and III-Medium red rice) inoculated by cyanobacteria Anabaena sp. and soaked by water to control

\section{Result and discussion}

In the result of conducted research on soil of paddy fields in Afghanistan (Shamarq and Chashmaishir villages of Baghlan province). Pure culture of cyanobacteria of Anabaena sp. was isolated with the help of standard microbiological and algological research methods and morphologically identified with the help of MX 300T (Austria) and Axio Imager A1 («Carl Zeiss», Germany) microscopes (figure1).

According to the evaluation of conducted research, isolated cyanobacteria Anabaena sp had positive effect on three common varieties of Afghanistan's rice (IR rice, Long red rice and medium red rice). These varieties have good adaptation in Baghlan province. Germination of Inoculated seeds by caynobacteria extracts after 10 days compared to water control, the percentage of germinated seeds was 100 (figure 2). The result shows that caynobacteria Anabaena sp. had a positive effect on the growth of rice (germination, height of shoot and length of root system). The root length and plant height of one of the average plant from each experimented variety was measured by ruler, showed differences (figure 3 ) as well as the graph of measuring showed differences (figure4).

In the next stage new seeds of the three common varieties Afghanistan's rice was separetely cultivated in nonorganic silt soil and every 24 hours the cultivated seeds under the experiment 
were treated by $10 \mathrm{ml}$ cyanobacteria extracts and sterile water to control. After 12 days the result showed that there are morphological differences in height of treated plant by caynobacteria Anabaena sp. in comparing to plant treated by water (figure5).

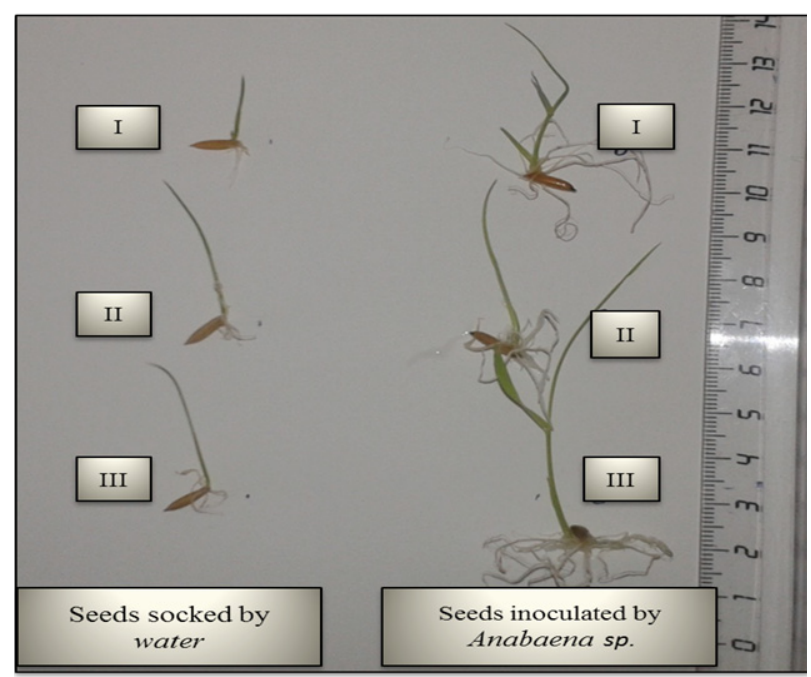

Figure 3 - The average effect of cyanobacteria Anabaena sp. on the root length and plant height of three varieties of rice

(I-IR rice, II-Long red rice and III-Medium red rice) in comparing to water control

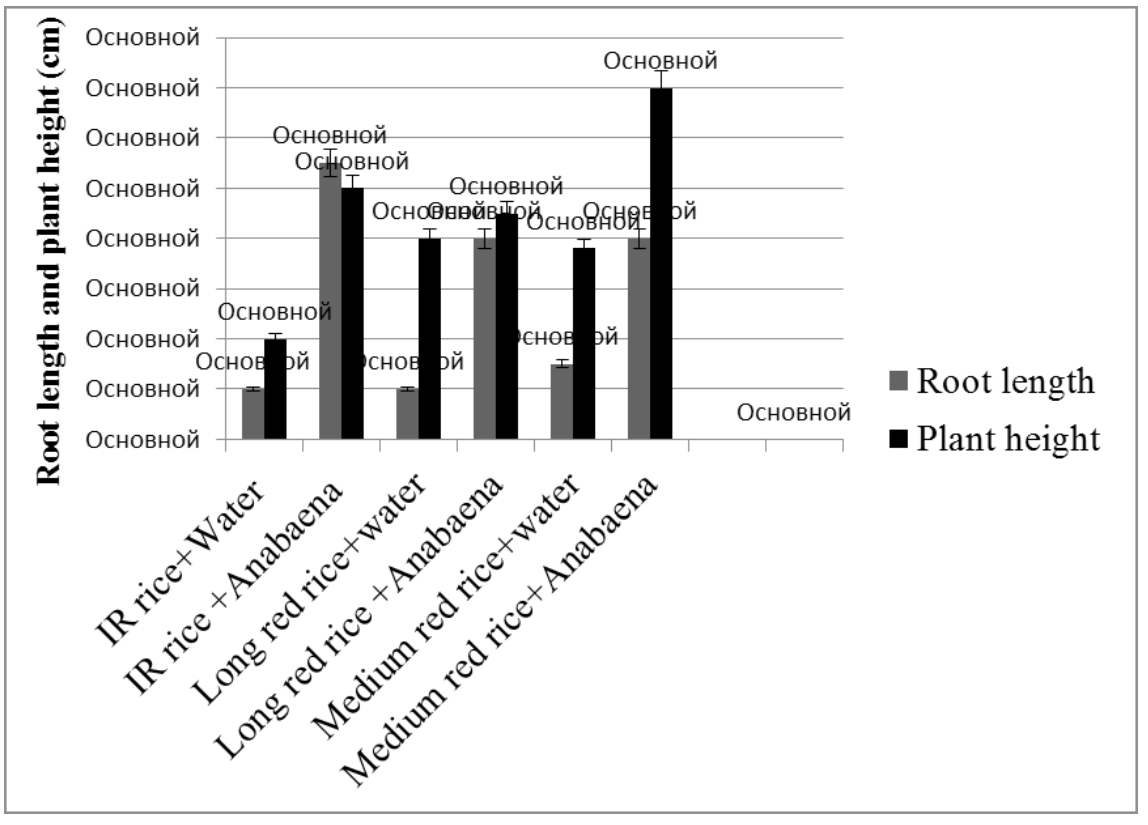

Figure 4 - The average effect of cyanobacteria Anabaena sp. on the root length and plant height of three varieties of rice ( IR rice, Long red rice and Medium rice) in comparing to water control 


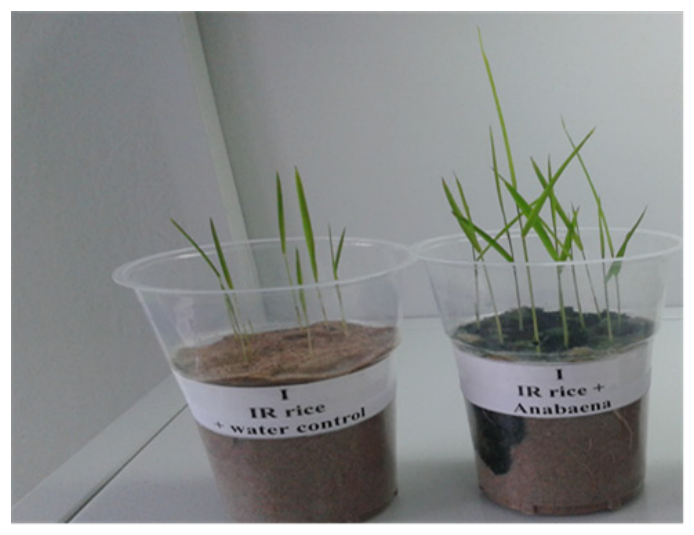

$$
\text { I+ Water I+ Anabaena }
$$

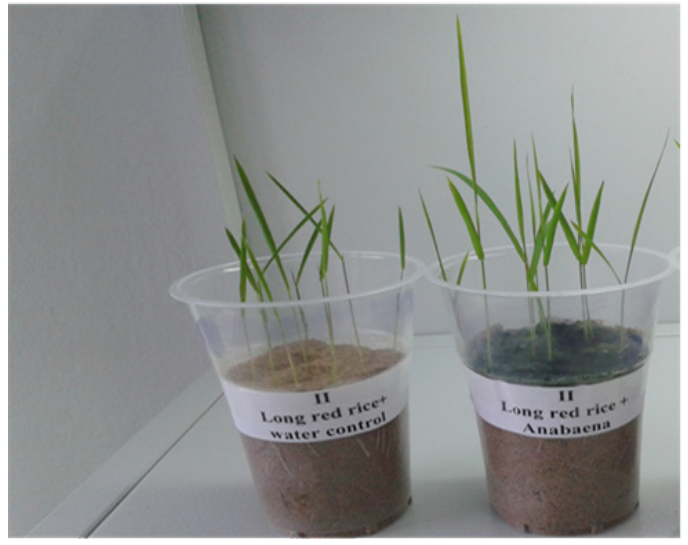

$$
\text { II+ Water II +Anabaena }
$$

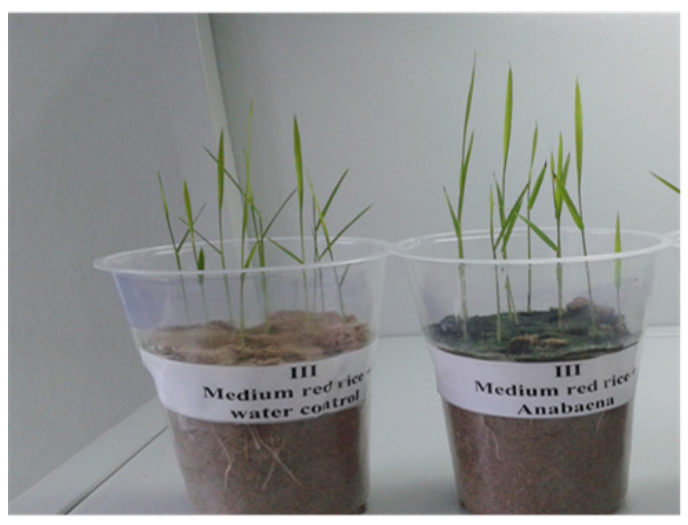

$$
\text { III+ Water III + Anabaena }
$$

Figure 5 - Shows the morphological comparing of three varieties of rice

( I-IR rice, II-Long red rice and III-medium red rice) treated by Anabaena sp. and compared to water treated seeds from the same variety in soil

\section{Conclusion}

Cyanobacteria are photosynthetic and prokaryotic microorganisms they are found in all over the world. They contribute the growth of plant by supplying growth substances. In this research, cyanobacteria Anabaena sp was isolated from paddy soils of Baghlan Province in Afghanistan and used as inoculums on three common varieties of Afghanistan's rice (IRric, Long red rice and medium red rice). The result revealed that treatment of rice seeds by cyanobacteria extracts can enhance seed 
germination and plant growth in all treated seeds as compared to control. In the next stage, cyanobacteria as inoculums experimented on cultivated rice in soil. The morphological view also showed differences in shoots height of treated plants as compared to control by water. Therefore cyanbacteria Anabaena $\mathrm{sp}$. is recommended as an effective biofertilizer in paddy fields.

\section{References}

1 Paerl HW, Pinckney JL., Steppe TF, «Cyanobacterial-bacterial mat consortia.: examining the functional unit of microbial survival and growth in extreme environments». Environ. Microbiol, 2(1) (2000): 11-26.

2 Karthikeyan A, Nagasathya AS, Priya E., Hypersaline. «Cyanobacterium: A Potential Biofertilizer for Vigna mungo.» L (Black Gram). Am.-Eur. J. Sustain. Agric, 2(1) (2008): 87-91.

3 Kirlwood AE, Buchheim JA, Buchheim MA, Henley WJ. «Cyanobacterial Diversity and Halotolerance in a Variable Hypersaline Environment.» Microbiol. Ecol, (55) (2008): 453-465.

4 Malik F.R., Ahmed S., Rizki Y.M. «Utilization of lignocellulosic waste for the preparation of nitrogenous biofertilizer.» Pakistan Journal of Biological Sciences, (4) (2001): 1217-1220.

5 Choudhury A.T.M.A., Kennedy I.R. «Nitrogen fertilizer losses from rice soils and control of environmental pollution problems.» Communications in Soil Science and Plant Analysis, (36) (2005): 1625-1639.

6 Rai M.K., «Handbook of Microbial Biofertilizer» Haworth Press, New York,(2006): 1-28.

7 Board N. «The Complete Technology Book on Biofertilzer and Organic Farming.Delhi,(2004):9-49

8 Song T., Martensson L., Eriksson T., Zheng W., Rasmussen U. «Biodiversity and seasonal variation of the cyanobacterial assemblage in a rice paddy field in Fujian, China.» The Federation of European Materials Societies Microbiology Ecology, (54) (2005): 131-140.

9 Roger P.A., Reynaud P.A. «Free-living Blue-green Algae in Tropical Soils.» springer,(5)(1982):147-168

10 Rodriguez A.A., Stella A.A., Storni M.M., Zulpa G., Zaccaro M.C. «Effects of cyanobacterial extracellular products and gibberellic acid on salinity tolerance in Oryza sativa L.» Saline System, 2:7(2006):1-4., accessed April 10 2017 doi:10.1186/1746$1448-2-7$

11 Wilson L.T. «Cyanobacteria: A Potential Nitrogen Source in Rice Fields.» Texas Rice, (6) (2006): 9-10.

12 Moussa TAA, Shanab SMM. «Impact of cyanobacterial toxicity stress on the growth activities of some phytopathogenic Fusarium sp.» AZ J. Microbiol., (53) (2001): 267-281.

13 Rizk MA. «Growth activities of the Sugarbeet Pathogen Sclerotium rolfsii Sacc., Rhizoctonia solani Khun. and Fusarium verticilloides Sacc. under cyanobacterial filtrate stress.» Plant Pathol. J., 5(2) (2006): 212-215.

14 Kim JD. «Screening of cyanobacteria (blue-green algae) from rice paddy soil for antifungal activity against plant pathogenic fungi.» Mycobiol., (34)(2006): 138-142.

15 Abo-Shady AM, Al-ghaffar BA, Rahhal MMH and Abd-El Monem HA. «Biological control of faba bean pathogenic fungi by three cyanobacterial filtrates.» Pakistan J. Biol. Sci., 10: (2007). 3029-3038.

16 Tassara C, Zaccaro MC, Storni MM, Palma M, Zulpa G. «Biological control of lettuce white mold with cyanobacteria.» Int. J. Agric. Biol., 10: (2008): 487-492.

17 Kim J, Kim J. «Inhibitory Effect of Algal Extracts on Mycelial Growth of the Tomato-Wilt Pathogen, Fusarium oxysporum f. sp. Lycopersici.» Mycobiol., 36(4) (2008): 242-248.

18 Hill DR, Peat A, Potts M. «Biochemistry and structure of the glycan secreted by desiccation-tolerant Nostoc commune (Cyanobacteria).» Protoplasma, 182: (1994):126-148.

19 Mazor G, Kidron GJ, Vonshak A, Abeliovich A. «The role of cyanobacterial exopolysaccharides in structuring desert microbial crusts.» FEMS Microbiol. Ecol., 21 (1996): 121-130.

20 Maqubela MP, Mnkeni PNS, Issa MO, Pardo MT, D’Acqui LP. «Nostoc cyanobacterial inoculation in South African agricultural soils enhances soil structure, fertility and maize growth.» Plant Soil, 315: (2009): 79-92.

21 De Caire GZ, De Cano MS, Palma RM, De Mule CZ. «Changes in soil enzyme activities following additions of cyanobacterial biomass and exopolysaccharide.» Soil Biol. Biochem., 32: (2000): 1985-1987.

22 De Cano MMS, De Caire GZ, De Mulé MCZ, Palma RM. «Effect of Tolypothrix tenuis and Microchaete tenera on biochemical soil properties and maize growth.» J. Plant Nutr., 25: (2002): 2421-2431.

23 Azia MA, Hashem MA. «Role of Cyanobacteria on yield in saline soil.» Pak. J. Biol. Sci., 7(3): (2004): 309-311.

24 Pandey KD, Shukla PN, Giri DD, Kashyap AK. «Cyanobacteria in alkaline soil and the effect of cyanobacteria inoculation with pyrite amendments on their reclamation.» Biol. Fert. Soils, 41: (2005): 451-457.

25 Malam Issa O, Defarge C, Bissonnais YL, Marin BD, Bruand A, D’Acqui LP, Nordenberg S, Annerman M. «Effects of the inoculation of cyanobacteria on the microstructure and the structural stability of a tropical soil.» Plant Soil, 290: (2007): 209-219.

26 Obana S, Miyamoto K, Morita S, Ohmori MI. «Effect of Nostoc sp. on soil characteristics, plant growth and nutrient uptake.» 16: (2007): 641-646.

27 Nisha R, Kaushik A, Kaushik CP. «Effect of cyanobacterial application on structural stability and productivity of an organically poor semi-arid soil.» Geoderma, 138: (2007): 49-56.

28 Swarnalakshmi K, Dhar DW, Singh PK. «Evaluation of blue-green algal inoculation on specific soil parameters.» Acta Agron. Hung., 55(3) (2007): 307-313.

29 Saadatnia H, Riahi H. «Cyanobacteria from paddy fields in Iran as biofertilizer in rice plants.» Plant Soil Environ., 55(5): (2009): 207-212.

30 Mishra U., Pabbi S. «Cyanobacteria: a potential biofertilizer for rice.» Resonance, (2004): 6-10. 
31 Kondo M., Yasuda M. «Seasonal changes in N2 fixation activity and N enrichment in paddy soils as affected by soil management in the northern area of Japan.» Japan Agricultural Research Quarterly, 37: (2003): 105-111.

32 Голлербах М.М., Косинская Е.К., Полянский В.И. «Определитель пресноводных водорослей СССР» // Вып. 4. Диатомовые водоросли. М., 1951. - С. 644.

\section{References}

1 Abo-Shady AM, Al-ghaffar BA, Rahhal MMH and Abd-El Monem HA (2007). Biological control of faba bean pathogenic fungi by three cyanobacterial filtrates. Pakistan J. Biol. Sci., 10: 3029-3038.

2 Azia MA, Hashem MA (2004). Role of Cyanobacteria on yield in saline soil. Pak. J. Biol. Sci., 7(3): 309-311.

3 Board N. (2004): The Complete Technology Book on Biofertilizer and Organic Farming, New Delhi.9-49

4 Choudhury A.T.M.A., Kennedy I.R. (2005): Nitrogen fertilizer losses from rice soils and control of environmental pollution problems. Communications in Soil Science and Plant Analysis, 36: 1625-1639.

5 De Caire GZ, De Cano MS, Palma RM, De Mule CZ (2000). Changes in soil enzyme activities following additions of cyanobacterial biomass and exopolysaccharide. Soil Biol. Biochem., 32: 1985-1987.

6 De Cano MMS, De Caire GZ, De Mulé MCZ, Palma RM (2002). Effect of Tolypothrix tenuis and Microchaete tenera on biochemical soil properties and maize growth. J. Plant Nutr., 25: 2421-2431.

7 Gollerbah M.M., Kosinskaya E.K., Polyanskiy V.I. (1951) «The determinant of freshwater algae of the USSR.» [Opredelitel presnovodnyh vodorosley. Diatomovie vodorosli] 4: 644. (In Russian)

8 Hill DR, Peat A, Potts M (1994). Biochemistry and structure of the glycan secreted by desiccation-tolerant Nostoc commune (Cyanobacteria). Protoplasma, 182: 126-148.

9 Karthikeyan A, Nagasathya AS, Priya E (2008). Hypersaline Cyanobacterium: A Potential Biofertilizer for Vigna mungo. L (Black Gram). Am.-Eur. J. Sustain. Agric., 2(1): 87-91.

10 Kim J, Kim J (2008). Inhibitory Effect of Algal Extracts on Mycelial Growth of the Tomato-Wilt Pathogen, Fusarium oxysporum f. sp. Lycopersici. Mycobiol., 36(4): 242-248.

11 Kim JD (2006). Screening of cyanobacteria (blue-green algae) from rice paddy soil for antifungal activity against plant pathogenic fungi. Mycobiol., 34: 138-142.

12 Kirlwood AE, Buchheim JA, Buchheim MA, Henley WJ (2008). Cyanobacterial Diversity and Halotolerance in a Variable Hypersaline Environment. Microbiol. Ecol., 55: 453-465.

13 Kondo M., Yasuda M. (2003): Seasonal changes in N2 fixation activity and N enrichment in paddy soils as affected by soil management in the northern area of Japan. Japan Agricultural Research Quarterly, 37: 105-111.

14 Malam Issa O, Defarge C, Bissonnais YL, Marin BD, Bruand A, D’Acqui LP, Nordenberg S, Annerman M (2007). Effects of the inoculation of cyanobacteria on the microstructure and the structural stability of a tropical soil. Plant Soil, 290: 209-219.

15 Malik F.R., Ahmed S., Rizki Y.M. (2001): Utilization of lignocellulosic waste for the preparation of nitrogenous biofertilizer. Pakistan Journal of Biological Sciences, 4: 1217-1220.

16 Maqubela MP, Mnkeni PNS, Issa MO, Pardo MT, D’Acqui LP (2009). Nostoc cyanobacterial inoculation in South African agricultural soils enhances soil structure, fertility and maize growth. Plant Soil, 315: 79-92.

17 Mazor G, Kidron GJ, Vonshak A, Abeliovich A (1996). The role of cyanobacterial exopolysaccharides in structuring desert microbial crusts. FEMS Microbiol. Ecol., 21: 121-130.

18 Mishra U., Pabbi S. (2004): Cyanobacteria: a potential biofertilizer for rice. Resonance, 6-10.

19 Moussa TAA, Shanab SMM (2001). Impact of cyanobacterial toxicity stress on the growth activities of some phytopathogenic Fusarium sp. AZ J. Microbiol., 53: 267-281.

20 Nisha R, Kaushik A, Kaushik CP (2007). Effect of cyanobacterial application on structural stability and productivity of an organically poor semi-arid soil. Geoderma, 138: 49-56.

21 Obana S, Miyamoto K, Morita S, Ohmori MI (2007). Effect of Nostoc sp. on soil characteristics, plant growth and nutrient uptake. 16: 641-646.

22 Paerl HW, Pinckney JL, Steppe TF (2000). Cyanobacterial-bacterial mat consortia: examining the functional unit of microbial survival and growth in extreme environments. Environ. Microbiol., 2(1): 11-26.

23 Pandey KD, Shukla PN, Giri DD, Kashyap AK (2005). Cyanobacteria in alkaline soil and the effect of cyanobacteria inoculation with pyrite amendments on their reclamation. Biol. Fert. Soils, 41: 451-457.

24 Rai M.K. (2006): Handbook of Microbial Biofertilizers. Haworth Press, New York.1-28.

25 Rizk MA (2006). Growth activities of the Sugarbeet Pathogen Sclerotium rolfsii Sacc., Rhizoctonia solani Khun. and Fusarium verticilloides Sacc. under cyanobacterial filtrate stress. Plant Pathol. J., 5(2): 212-215.

26 Rodriguez A.A., Stella A.A., Storni M.M., Zulpa G., Zaccaro M.C. (2006): Effects of cyanobacterial extracellular products and gibberellic acid on salinity tolerance in Oryza sativa L. Saline System, 2:7.2-4 , accessed April 10, 2017 doi:10.1186/1746-1448-2-7

27 Roger P.A., Reynaud P.A. (1982): Free-living Blue-green Algae in Tropical Soils. springer Vol 5 pp 147-168

28 Saadatnia H, Riahi H (2009). Cyanobacteria from paddy fields in Iran as biofertilizer in rice plants. Plant Soil Environ., 55(5): 207-212

29 Song T., Martensson L., Eriksson T., Zheng W., Rasmussen U. (2005): Biodiversity and seasonal variation of the cyanobacterial assemblage in a rice paddy field in Fujian, China. The Federation of European Materials Societies Microbiology Ecology, 54: 131-140.

30 Swarnalakshmi K, Dhar DW, Singh PK (2007). Evaluation of blue-green algal inoculation on specific soil parameters. Acta Agron. Hung., 55(3): 307-313

31 Tassara C, Zaccaro MC, Storni MM, Palma M, Zulpa G (2008). Biological control of lettuce white mold with cyanobacteria. Int. J. Agric. Biol., 10: 487-492.

32 Wilson L.T. (2006): Cyanobacteria: A Potential Nitrogen Source in Rice Fields. Texas Rice, 6: 9-10. 